\title{
Lipoxin A4 a novel therapeutic agent for the treatment of breast cancer metastases
}

\author{
Browne $\mathrm{E}^{1,2 *}$, Chen $\mathrm{H}^{1,2}$, Vencken $\mathrm{S}^{1,2}$ and Condron $\mathrm{CM}^{1,2}$ \\ ${ }^{1}$ Department of Surgery, Royal College of Surgeons Ireland \\ ${ }^{2}$ Education and Research Centre, Beaumont Hospital, Ireland
}

\begin{abstract}
Clinical data for solid tumours show a correlation between high-density leukocyte infiltration and poor patient outcomes. Tumour-associated neutrophils (TAN) and macrophages (TAM) can account for $50 \%$ of the total tumour mass in invasive breast carcinomas and these inflammatory cells positively influence tissue remodeling and the development of angiogenic vasculature by producing pro-angiogenic mediators and extracellular proteases. Lipoxins (LXs), trihydroxytetraene-containing eicosanoids, are endogenous "braking signals" for inflammation. LXs down regulate pro-inflammatory cytokines, inhibit matrix metalloproteinase 9 (MMP-9), vascular endothelial growth factor (VEGF), and Hypoxia Induced Factor (HIF) and may act as a selective estrogen-receptor modulator (SERM). We hypothesis that $\mathrm{LXA}_{4}$ can alter immune tolerance and augment anti-tumour immune responses in breast cancer.

Methods: The metastatic human breast adenocarcinoma cell line MDA-MB-231 and the murine 4T1 breast cancer cell line were grown in culture and tumour conditioned medium (TCM) harvested, by centrifugation at $900 \mathrm{~g}$, filtered $(0.22 \mu \mathrm{m})$ and stored at $-20^{\circ} \mathrm{C}$. Human neutrophils were analysed from healthy volunteers blood. Cell surface receptor expression was assessed by flow cytometry using FITC-conjugated anti-mouse IACM-1 Mab, PE-conjugated anti-human CD11b and FITC-conjugated anti-human CD62L. Tumour cell invasion was assed using CytoSelect Cell Invasion culture plates. miRNA was isolated using miRNeasy) and reverse transcribed using TaqMan. miRNA expression was normalized to the values of the internal control Sno135.

Results: LXA $_{4}(200 \mathrm{~nm})$ treatment significantly reduced CD11b adhesion receptor expression on human neutrophils induced by incubation with tumour conditioned medium (985 \pm 24.88 MCF: TCM vs $806 \pm 61.23$ MCF: $\mathrm{p}<0.05$, ANOVA). Treatment with LXA4 also reversed L-selectin shedding from both human and murine neutrophils induced by TCM $(36.21 \pm 1.86$ vs $47.41 \pm 5.8$ and $70.53 \pm 2.11$ vs $108.59 \pm 12.06$, respectively p $<0.05$ ANOVA). In addition, LXA suppressed breast cancer cell invasion $(77 \pm 9$ cell/field IL-1 $\beta(10 \mathrm{ng} / \mathrm{ml})$ vs $57 \pm 7$ cell/field IL-1 $\beta+\mathrm{LXA} 4(200 \mathrm{~nm}) \mathrm{p}<0.05$, ANOVA), and weakened metastatic potential by modulating tumour cell ICAM-1 expression in vitro (248.06 $\pm 53.0 \mathrm{MCF}$ IL-1 $\beta(10 \mathrm{ng} / \mathrm{ml})$ vs 129.5 $\pm 46.23 \mathrm{MCF}$ IL-1 $\beta+\mathrm{LXA} 4$ (10nm) p<0.05, ANOVA n=4 on MDA-MB231; $91.91+-$ 6.5 MCF IL-1 $\beta(10 \mathrm{ng} / \mathrm{ml})$ vs 49.32 $\pm 9.4 \mathrm{MCF}$ IL-1 $\beta+\mathrm{LXA} 4(200 \mathrm{~nm}) \mathrm{p}<0.01$, ANOVA $\mathrm{n}=3$ on $4 \mathrm{~T} 1)$. LXA4 deceased secretion of matrix metalloproteinases $(5.03 \pm 0.78 \mathrm{IL}-1 \beta$ vs $3.98 \pm 0.47(\mathrm{ng} / \mathrm{ml}) \mathrm{IL}-1 \beta+\mathrm{LXA} 4100 \mathrm{~nm}$ in MDA-MB231 cells and $(288.7 \pm 16.9 \mathrm{IL}-1 \beta \mathrm{vs} 228.7 \pm 36.48(\mathrm{ng} / \mathrm{ml}) \mathrm{IL}-1 \beta+\mathrm{LXA} 4100 \mathrm{~nm}) \mathrm{in} 4 \mathrm{~T} 1$ cells). Furthermore $\mathrm{LXA}_{4}$ treatment at $4 \mathrm{hr}$ significantly increased human ( 2.5 fold change) and murine $4 \mathrm{~T} 1$ (1.6 fold change) tumour cell expression of miRNA 146.

Discussion: Transduction of miR-146 into breast cancer cells has been shown to inhibited invasion, migration in vitro, and significantly suppressed lung metastasis in a murine model. We demonstrate for the first time that LXA4 can augment miRNA 146 expression. Taken together, these results indicate that LXA4 has the potential to reduce breast cancer metastatic spread. Combination antiangiogenic therapeutic strategies that target both tumour-related inflammation and angiogenesis may prove successful where anti VEGF strategies alone have failed. Further investigation of LXA4 as a potential anti-tumour agent is merited in an in vivo murine model of breast cancer.
\end{abstract}

\section{Introduction}

Breast cancer is the second most commonly occurring cancer worldwide and there were over 2 million new cases diagnosed in 2018 [1]. Further, approximately $85 \%$ of such patients receive surgical intervention [2], as resection remains the essential curative modality for breast cancer. However, surgical manipulations disrupt the structural integrity of the tumour, shedding malignant cells into the circulation and increasing the risk of metastasis. A recent epidemiological study looking at non-surgically and surgically managed breast cancer patients, demonstrated that while the former displayed a peak of mortality at 4 years follow up, the latter demonstrated another distinctive peak at 8 years [3]. A century of investigation has begun to elucidate a connection between surgical resections and a counter-intuitive increased risk for distant metastasis [4,5]. In animal models, surgical resection has been shown to increase perioperative tumour shedding into local blood and lymphatic channels due to physical manipulation [5]. In vitro models have revealed that surgery can enhance invasive potential through inducing the release of matrix metalloproteinases (MMP-9) and triggering the expression of cellular adhesion molecules (ICAM) on tumour cell surfaces [5]. Growth factors released due to cell injury (EGF, IL-6) and hypoxia (VEGF) are highly up regulated during times of surgical stress, further potentiating the likelihood of tumour embolization and micro-metastasis [6]. These considerations are particularly significant because approximately $90 \%$ of cancer related mortality is directly the result of local invasion and distant metastasis [7]. There exists a gap in clinical practise as to how this deleterious

${ }^{*}$ Correspondence to: Claire Condron, Department of Surgery, R.C.S.I. Education and Research Centre, Dublin 9, Ireland, Tel: 353-1-8092687, Fax: $353-$ 1-8093335, E-mail: ccondron@rcsi.ie

Key words: breast cancer, metastases, adhesion receptor, tail vein

Received: April 21, 2020; Accepted: May 10, 2020; Published: May 13, 2020 
perioperative environment could be modulated to improve long-term outcomes.

Lipoxin A4 (LXA4), a trihydroxytetraene containing an arachidonic acid (AA) derivative, is classified under the category of eicosanoids [8]. Contrary to the pro-inflammatory profile of the better-studied eicosanoids such as prostaglandins and leukotriene's, lipoxins have been shown to exhibit potent anti-inflammatory and anti-angiogenic properties $[9,10]$. Lipoxins are believed to exert their cellular responses through their stereospecific agonist activity at the G-protein coupled AXL receptor, triggering intracellular calcium mobilization and further intracellular signaling pathways currently less well understood $[8,9]$. LXA4 has a well-established experimental capacity to alter the pro-inflammatory milieu of invasive [9-14]. Within invasive breast cancers, tumor associated macrophages (TAM's) can represent up to $50 \%$ of total tissue [15]. TAM's primarily represent a phenotypic switch from ordinary M1 to M2 macrophages that promote neo-angiogenesis, tumor growth, tumor invasion, matrix remodeling and suppression of the adaptive immune system via altered chemokine profiles $[16,17]$. LXA4 treatment can transform altered M2 macrophages to the classic M1 phenotype associated with an anti-tumorigenic scope that includes markedly increased phagocytic power and reactive oxygen species generation [12]. Increased vascular growth factor (VEGF) expression has been strongly correlated with poor prognostic outcomes in breast carcinoma's [18]. Multiple studies have demonstrated that LXA4 exposure can drastically reduce VEGF and hypoxia induced factor (HIF-1a) expression thereby reducing tumor growth and angiogenesis [9-11,13]. Additionally, reduced VEGF expression in the perioperative period could reduce micro metastasis by blocking VEGFR-2 signaling cascades that induce local endothelial permeability to tumor cells [14].

Tumour suppressor microRNAs (miRNAs)) and oncogenic miRNAs (oncomiRs) are implicated in cancer development 4 and malignancies have been classified based on the expression profiles of individual miRNAs [19,20]. Certain miRNAs such as miR-126, miR-335 and miR-146, which are differentially expressed in breast cancer, have been functionally linked with metastatic stage' [21,22]. Increasingly studies suggested that the miR-146 family plays a role in inflammatory process and miR-146a has been shown to be correlated with BRCA1 expression, the human tumour suppressor gene that codes for breast cancer type 1 susceptibility protein [23]. Transduction of miR-146 into breast cancer cells down-regulates expression of epidermal growth factor receptor, inhibites invasion and migration in vitro and significantly suppresses lung metastasis in a murine model [24]. Many silenced miRNAs appear to act as tumour suppressors by targeting oncogenes, thus re-expression of the miRNAs could be an effective approach to cancer therapy [25]. LXA4 has been shown to mediate miRNA expression and its transfer via microvesicles [26].

The perioperative period offers a therapeutic window to improve patient outcomes with adjuvant treatment [27] yet no suitable therapy currently exists. Lipid mediators may break immune tolerance and augment anti-tumour immune responses at the time of surgery. Combination antiangiogenic therapeutic strategies that target both tumour-related inflammation and angiogenesis may prove successful where anti VEGF strategies alone have failed. The aim of this work is to evaluate LXA4 as a potential perioperative adjunct treatment for breast cancer surgery with particular attention to metastatic invasion capacity.

\section{Methods}

The metastatic human breast adenocarcinoma cell line MDAMB-231 was obtained from the American Type Culture Collection
(ATCC, Rockville, MD). The murine $4 \mathrm{~T} 1$ breast cancer cell line was obtained from the American Type Culture Collection (Manassas, VA). MDA-MB231 and 4T1 cells were grown in DMEM or RPMI 1640 medium, respectively, supplemented with $10 \%$ FCS, penicillin(100units/ $\mathrm{ml})$, streptomycin sulphate $(100 \mu \mathrm{g} / \mathrm{ml})$, and $2.0 \mathrm{mM}$ glutamine. Cells were maintained at $37{ }^{\circ} \mathrm{C}$ in a humidified $5 \% \mathrm{CO}_{2}$ atmosphere and subcultured by trypsinization with $0.05 \%$ trypsin-0.02\%EDTA when cells became confluent.

\section{Tumour Conditioned Medium (TCM)}

MDA-MB231 or $4 \mathrm{~T} 1$ cells $\left(5 \times 10^{5} /\right)$ were grown to subconfluency $(\sim 80 \%)$ in culture medium, washed $3 \mathrm{x}$ with $\mathrm{PBS}$ and treated with medium only as a control, IL-1 $\beta$ (20ng/ml for MDA-MB231 or 10ng/ $\mathrm{ml}$ for $4 \mathrm{~T} 1)$, RvD1 only or RvD1 plus IL-1 $\beta$ (200nM, $100 \mathrm{nM}$ and $10 \mathrm{nM}$, respectively) in fresh culture medium at $37^{\circ} \mathrm{C}$ in $5 \% \mathrm{CO}_{2}$ for $24 \mathrm{~h}$. TCM was then harvested, centrifuged at $900 \mathrm{~g}$ and $4^{\circ} \mathrm{C}$ for $20 \mathrm{~min}$. passed through $0.22-\mu \mathrm{m}$ pore-sized filters (Gelman Sciences, Ann Arbor, MI), and stored at $-20^{\circ} \mathrm{C}$ until use.

\section{Adhesion receptor expression}

ICAM-1 expression on MDA-MB231 and 4T1 cells was assessed by flow cytometry as previously described. Briefly, cells were grown to subconfluency and incubated with $40 \mathrm{ng} / \mathrm{ml} \mathrm{IL-} \beta$ as a stimulant and treated with either $200 \mathrm{nM}, 100 \mathrm{nM}$ or $10 \mathrm{nM}$ of $\mathrm{LXA}_{4} .100 \mu$ l of cells suspension $\left(0.2 \times 10^{6} / \mathrm{ml}\right)$ were incubated with $1 \mu \mathrm{l}$ of FITC-conjugated anti-mouse IACM-1 MAb or $5 \mu$ l of FITC-conjugated anti human ICAM-1 MAb. FITC-conjugated mouse IgG1 $\mathrm{k}$ isotype was used as negative control. ICAM-1 receptor expression on the tumour cells was analysed on a FACSCalibur flow cytometer equipped with an argon laser excitation wavelength of $\lambda \mathrm{ex}=488 \mathrm{~nm}$. A minimum number of 10,000 events were collected. The data was recorded on a logarithmic scale of the mean channel florescence (MCF) intensity and analysed using Lysis II software. The instrument was calibrated daily.

Measurement of Human blood polymorphonuclear leukocyte (PMN) L-selectin shedding: $100 \mu$ l of human fresh blood samples were incubated with $100 \mu \mathrm{l}$ of TCM at RT for $1 \mathrm{~h}$. Cells were then incubation at RT for 30 min with $5 \mu$ of FITC-conjugated anti-human CD62L. $5 \mu \mathrm{l}$ of FITC-conjugated isotype IgG1 $\mathrm{k}$ was used as negative control. After, L-selectin shed from PMN cells were analysed by flow cytometry.

$100 \mu$ l of fresh human or murine whole blood was incubated with $100 \mu$ l of tumour conditioned medium (TCM) (MDA or 4TI as appropriate) at room temperature (RT) for $1 \mathrm{~h}$. Cells were stained with $2 \mu \mathrm{l}$ of FITC-conjugated anti-mouse CD11b or $5 \mu \mathrm{l}$ of $\mathrm{PE}$-conjugated anti-human CD11b. $5 \mu \mathrm{l}$ of PE-conjugated anti-mouse Ly-6G, $2 \mu \mathrm{l}$ of FITC-conjugated isotype IgG or $5 \mu \mathrm{l}$ of PE-conjugated isotype IgG2a $\mathrm{k}$ were used as negative control. After incubation at $4^{\circ} \mathrm{C}$ for $30 \mathrm{~min}$, $\mathrm{CD} 11 \mathrm{~b}$ expression was analysed by flow cytometer.

\section{MMP-9 secretion}

Total MMP-9 secretion in cell culture supernatant was measured by ELISA according to the manufactures instructions. Briefly $50 \mu$ l of sample per well were incubated for $2 \mathrm{hr}$ at RT. After aspiration/wash $\mathrm{x}$ 3, 100 $\mu$ l of mouse total MMP-9 conjugate was added to each well and incubated for $2 \mathrm{~h}$ at RT. The aspiration/wash was repeated three times. $100 \mu \mathrm{l}$ of substrate solution then incubated for $30 \mathrm{~min}$ at RT. $100 \mu \mathrm{l}$ of stop solution was added and the optical density of each well determined using a Microtiter Plate Reader set to $450 \mathrm{~nm}$. (Victor ${ }^{\mathrm{TM}} \mathrm{X} 3$ multilable Reader PerkinElmer, Ohio, USA). 


\section{Tumour cell invasion}

Tumour cell invasion potential was assessed using CytoSelect

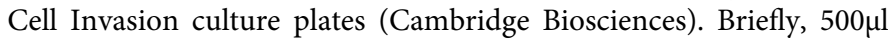
of medium containing $10 \%$ FBS was added to the lower well of the invasion chamber and $300 \mu$ of the treated cell suspension solution $\left(1.5 \times 10^{6} / \mathrm{ml}\right)$ to the top of each insert for $48 \mathrm{~h}$ at $37^{\circ} \mathrm{C}$ in $5 \% \mathrm{CO}_{2}$. The top side of the inserts were gently swabbed to remove non-invasive cells. The insert was transferred to $400 \mu$ l of stain solution and incubate for 10mins at RT. Invasive Tumour cells were counted with a light microscope with at least three individual fields per insert at 200x.

\section{miRNA expression}

Total RNAs was extracted using the miRNeasy Micro Kit (Qiagen) and reverse transcribed using the TaqMan MicroRNA Reverse Transcription Kit. The TaqMan Universal Master Mix II (Applied Biosystems) was used for quantitative PCR to determine mRNA levels. PCR was performed on a LightCycler 480 (Roche). Ct values were used for quantification of transcripts. miRNA expression was normalized to the values of Sno135, considered as internal control miRNAs. Data were acquired and analysed using the $2^{-\Delta \Delta \mathrm{Ct}}$ method [28].

\section{Results}

\section{Adhesion receptor expression}

CD11b: CD11b regulates leukocyte adhesion and migration and incubation with TCM for $1 \mathrm{~h}$ increased CD11b expression on human neutrophils compared to controls $(844.72 \pm 78.88 \mathrm{MCF} / \mathrm{cell}$ vs 984.96 $\pm 24.88 \mathrm{MCF} / \mathrm{cell}(\mathrm{p}<0.05$, Figure 1$)$. The addition of IL- $1 \beta$ further increased CD11b expression (1161.95 $\pm 70.25 \mathrm{MCF} / \mathrm{cell})$. Treatment with $\mathrm{LXA}_{4}$ significantly decreased CD11b expression induced by TCM $(870.23 \pm 74.69 \mathrm{MCF} /$ cell $)$ and IL-1 $\beta$ (921.46 \pm 32.03$)$.

L-selectin: L-selectin is cleaved during the multistep adhesion cascade regulating leucocyte invasion and this shedding is responsible for amplifying leukocyte recruitment [29]. TCM-induced L-selectin shedding from neutrophils compared to control $(36.21 \pm 1.86 \mathrm{MCF} / \mathrm{cell}$ vs $53.18 \pm 0.97 \mathrm{MCF} / \mathrm{cell}(\mathrm{p}<0.0001$, Figure $2 \mathrm{~A}$ ) and stimulation with IL-1 $\beta$ further increased shedding $(29.96 \pm 1.23 \mathrm{MCF} / \mathrm{cell})$. In contrast, treatment with $\mathrm{LXA}_{4}$ and the combination of Il-1 $\beta / \mathrm{LXA}_{4}$ significantly reversed this shedding to $49.21 \pm 3.33 \mathrm{MCF} / \mathrm{cell}(\mathrm{p}<0.001)$ and 39.0 $\pm 7.27(\mathrm{p}<0.078)$, respectively. TCM-induced murine L-selectin shedding compared to control $(70.54 \pm 2.11 \mathrm{MCF} /$ cell vs $101.27 \pm 10.9$ $\mathrm{MCF} /$ cell $(\mathrm{p}<0.01$, Figure $2 \mathrm{~B})$. The addition of IL- $1 \beta$ further increased to $50.96 \pm 10.0 \mathrm{MCF} /$ cell. In contrast, treatment with $\mathrm{LXA}_{4}$ and the

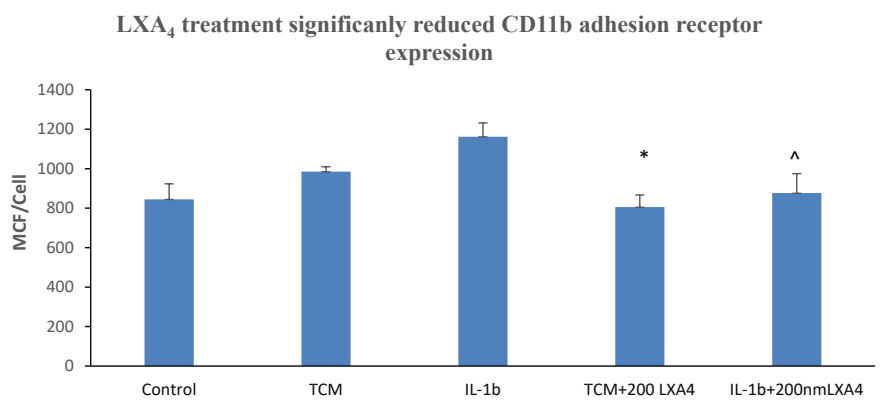

Figure 1. $\mathrm{LXA}_{4}$ treatment significantly reduced $\mathrm{CD} 11 \mathrm{~b}$ adhesion receptor expression on human neutrophils induced by incubation with tumour conditioned medium ${ }^{*}, \mathrm{p}<0.05$, ANOVA $n=5$. LXA treatment significantly reduced CD $11 \mathrm{~b}$ adhesion receptor expression on human neutrophils induced by incubation with IL-1 $\beta$. Data represent the mean $\pm \mathrm{SEM}$ $*, p<0.01$, ANOVA $n=5$.
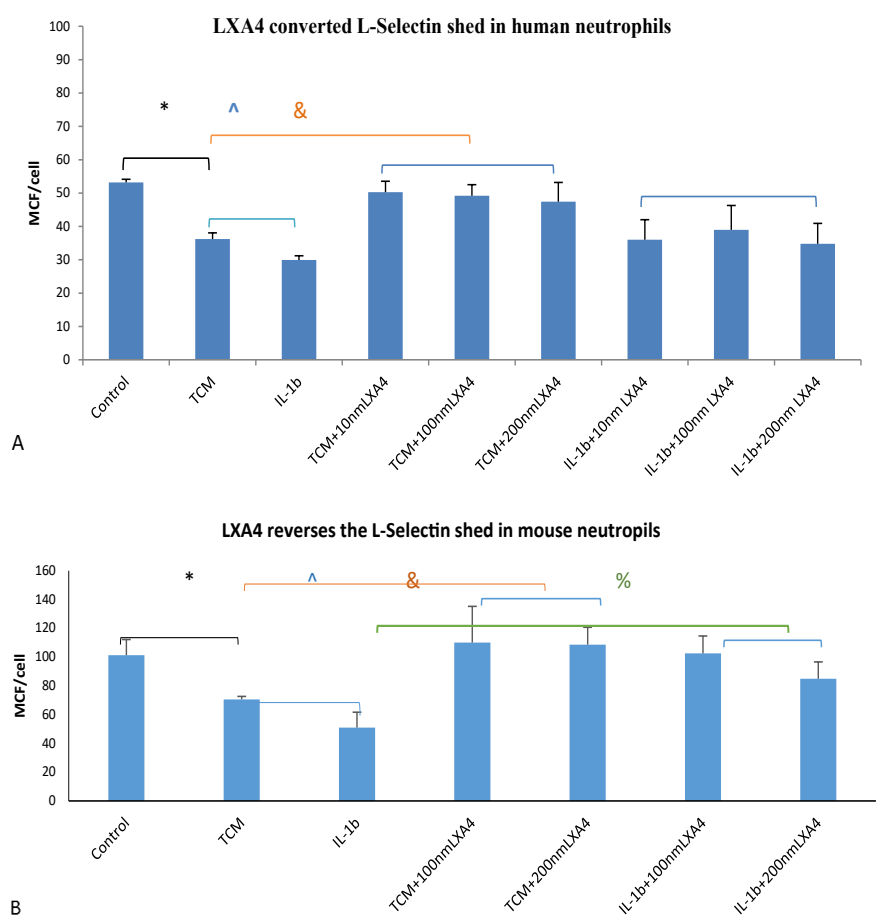

Figure 2. LXA treatment significantly reverses L-Selectin shedding from human and mouse neutrophils induced by incubation with tumour conditioned medium or IL- $1 \beta$. Data represent the mean \pm SEM $*, p<0.0001, \& p<0.001 \wedge p<0.078$ ANOVA $n=4$. For human neutrophils. (A). *, $\mathrm{p}<0.01, \&, \mathrm{p}<0.05, \%, \mathrm{p}<0.001$ ANOVA $\mathrm{n}=4$. For mouse neutrophils. (B )

combination of Il-1 $\beta / \mathrm{LXA}_{4}$ significantly reversed the shed to $110.08 \pm$ 25.15 MCF/cell $(\mathrm{p}<0.05)$ and $102.52 \pm 12.11(\mathrm{p}<0.001)$, respectively.

ICAM-1: ICAM-1 adhesion receptor activates cancer cells promoting cell motility, invasion, and metastasis [30]. Our experiments demonstrated that LXA $_{4}$ downregulated ICAM-1 expression on both murine and human breast cancer cells. After MDA-MB231 or 4T1 cell stimulated by the inflammatory factor IL- $1 \beta$, the expression of ICAM-1 increased from $50.63 \pm 2.82 \mathrm{MCF} /$ cell to $248.06 \pm 53.0 \mathrm{MCF} /$ cell, $\mathrm{p}<0.001$, treatment $\mathrm{LXA}_{4}$ for $24 \mathrm{~h}$ ICAM-1 decreased to $129.45 \pm$ 46.23 MCF/cell, $\mathrm{p}<0.05$ on MDA-MB231 (Figure $3 \mathrm{~A}$ ). Similarly, on $4 \mathrm{~T} 1$, the expression of ICAM-1 increased from $42.1 \pm 4.05 \mathrm{MCF} / \mathrm{cell}$ to 91.91 $\pm 6.49 \mathrm{MCF} /$ cell, $\mathrm{p}<0.001 \mathrm{LXA} 4$ reversed to $29.77 \pm 1.74 \mathrm{MCF} /$ cell, $\mathrm{p}<0.001$ (Figure $3 \mathrm{~B}$ ).

MMP-9: IL-1 $\beta$ stimulated an increased MMP-9 secretion from MDA-MB231 cells compared to the control $5.02 \pm 0.78$ vs $3.75 \pm 0.38$ $(\mathrm{ng} / \mathrm{ml}) \mathrm{p}<0.05$. Treatment with LXA4 significantly reduced this MMP9 secretion $3.98 \pm 0.47(\mathrm{ng} / \mathrm{ml}), \mathrm{p}<0.05, \mathrm{n}=5$. (Figure $4 \mathrm{~A}$ ). Similar results were found with $4 \mathrm{~T} 1$ cells where stimulation with IL- $1 \beta$ increased MMP-9 secretion $288.7 \pm 16.90(\mathrm{ng} / \mathrm{ml})$ compared to controls $237.6 \pm$ $39.33(\mathrm{ng} / \mathrm{ml}) \mathrm{p}<0.05$. and treatment with $\mathrm{LXA}_{4}$ significantly reduced to $228.7 \pm 36.48(\mathrm{ng} / \mathrm{ml}) \mathrm{p}<0.05, \mathrm{n}=5$ (Figure $4 \mathrm{~B}$ ).

Invasion: Stimulation with IL- $1 \beta$ increased MDA-MB231 invasion through a basement membrane compared with control $(76.7 \pm 8.94$ cells/field vs $58.5 \pm 4.37{ }^{*} \mathrm{p}<0.05 \mathrm{n}=4$ ). Treatment with $\mathrm{LAX}_{4}$ suppresses this stimulated invasion $\left(57.3 \pm 6.71\right.$ cells/field ${ }^{\wedge} p<0.05 n=4$. (Figure 5).

MiRNA: LX4 treatment alters miRNA expression of both Human MDA-MB231 (2.57 fold) and murine 4T1 (1.87 fold) breast cancer cells. A significant fold difference in the expression of miRNA between the LX4 treated and untreated breast cancer cells was noted in vitro at 4 hrs (Figure 6.) 


\section{$\mathrm{LXA}_{4}$ reduces ICAM-1 expression on MDA-MB231}

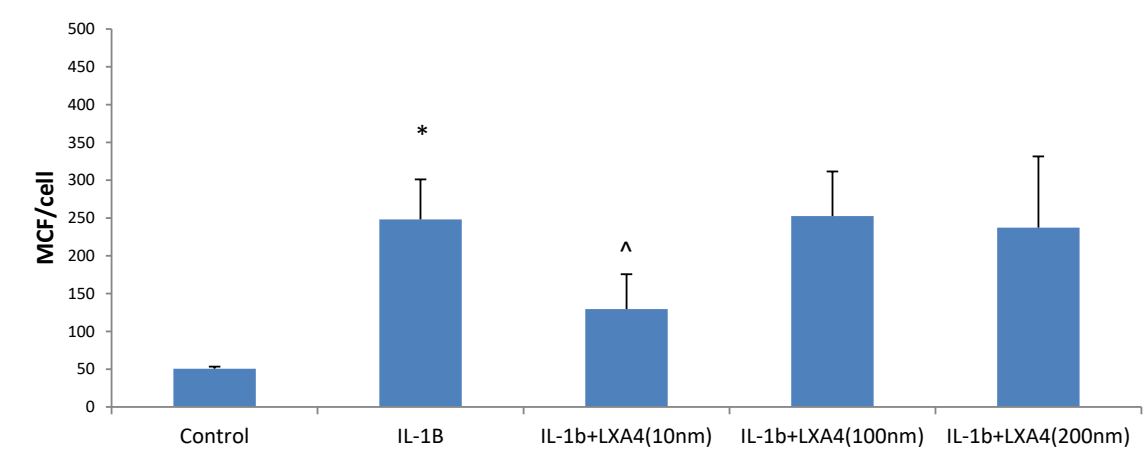

LXA4 reduces ICAM-1 expression on 4T1 cells

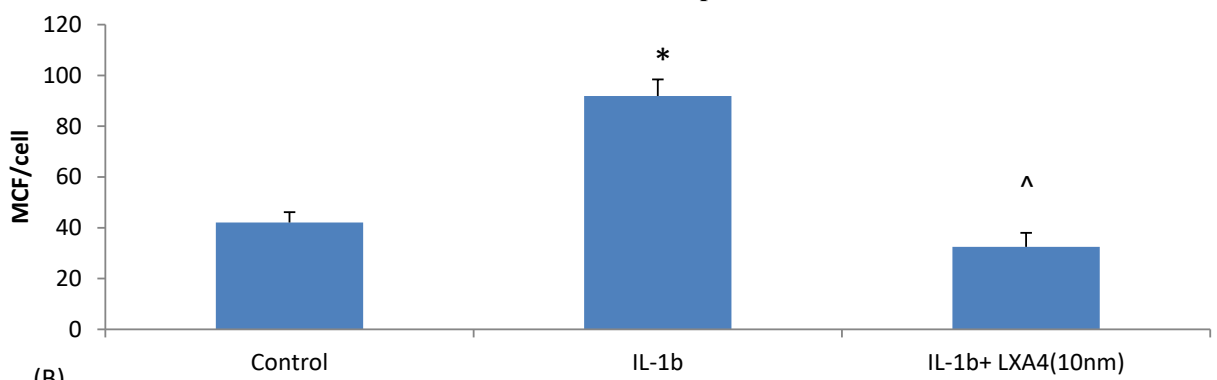

Figure 3. LXA $(10 \mathrm{~nm})$ reduces ICAM-1 surface expression on breast tumour cells following pre-treatment with IL- $1 \beta$ for 24 hours. Data represent the mean \pm SEM . $*$ p $<0.001$ IL-1 $\beta$ vs control medium, ${ }^{\wedge} \mathrm{p}<0.05 \mathrm{IL}-1 \beta+\mathrm{LXA}_{4}$ vs IL- $1 \beta$ ANOVA $n=4$ on human MDA-MB231 cells (A). $\quad{ }^{*} \mathrm{p}<0.001 \mathrm{IL}-1 \beta$ vs control medium, $\wedge \mathrm{p}<0.001 \mathrm{IL}-1 \beta+\mathrm{LXA} \mathrm{V}_{4}$ Vs IL-1 $\beta \quad$ ANOVA $\mathrm{n}=3$ on $4 \mathrm{~T} 1$ murine cells. (B)
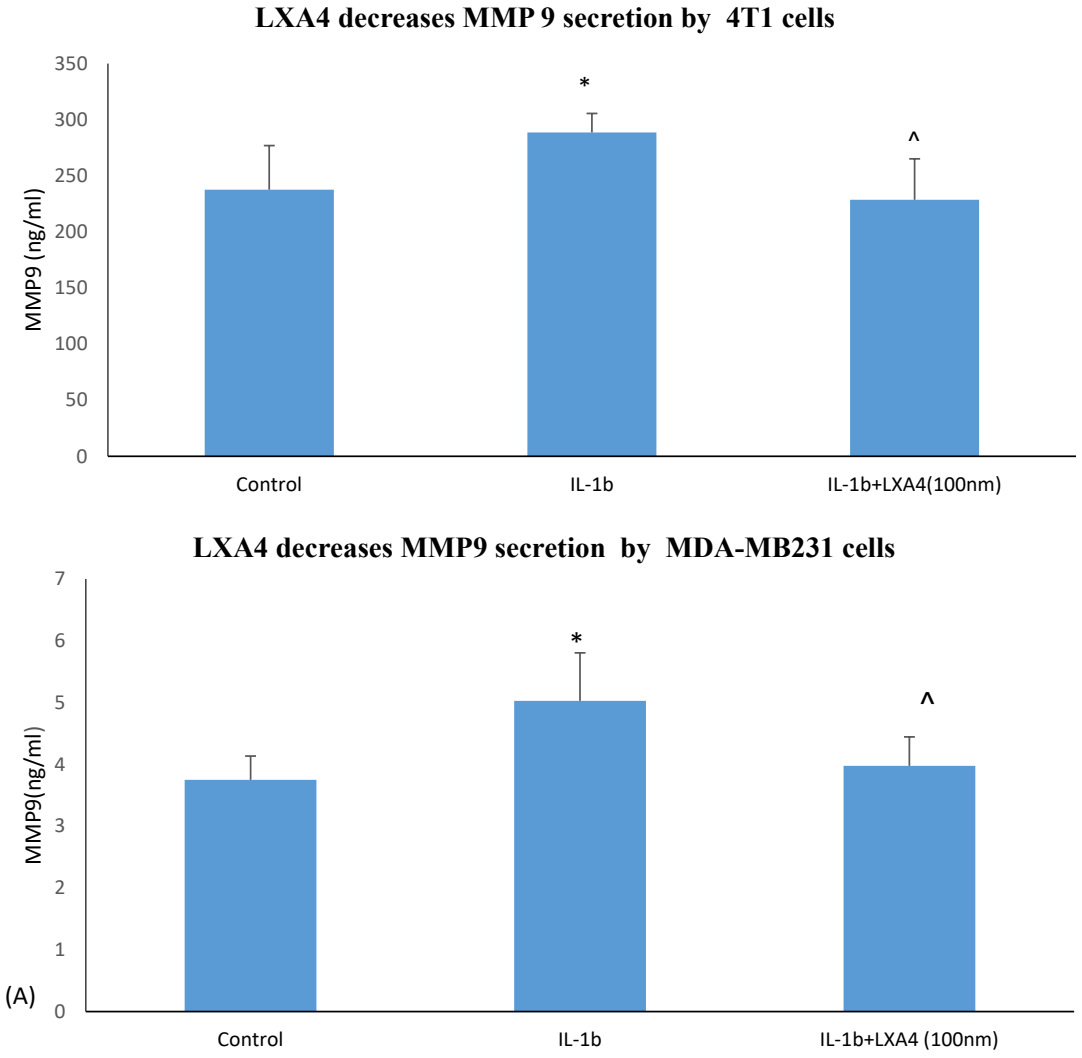

Figure 4. LXA $(100 \mathrm{~nm})$ reduces MMP9 secretion from breast cancer cells. Cell were pre-treatedt with IL-1 $\beta$ or IL- $1 \beta+\mathrm{LXA}$ for 24 hours. Data represent the mean \pm SDM. $* p<0.05$ IL$1 \beta$ vs control medium. ${ }^{\wedge} \mathrm{p}<0.05 \mathrm{IL}-1 \beta+\mathrm{LXA}_{4}$ vs IL- $1 \beta$ alone ANOVA $\mathrm{n}=4$ for MDA-MB231 cells (A). * $\mathrm{p}<0.05 \mathrm{IL}-1 \beta$ vs control medium, $\wedge \mathrm{p}<0.05$ IL- $1 \beta+\mathrm{LXA} 4 \mathrm{Vs}$ IL-1 $\beta \quad$ ANOVA $\mathrm{n}=3$ for $4 \mathrm{~T} 1$ (B). 


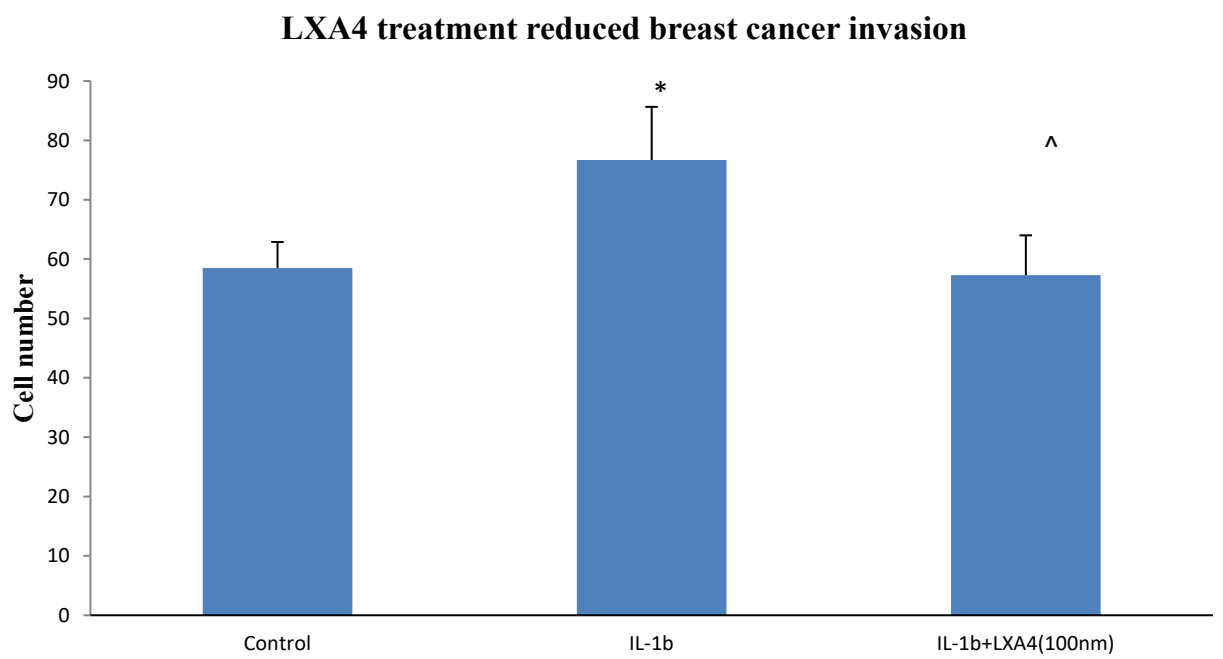

Figure 5. LXA suppressed IL-1 $\beta$ (10nM for 48hrs) stimulated MDA-MB-231 cell invasion through a matrigel-coated basement membrane. Invading cells were quantified under light microscopy in 10 random fields per Transwell. Data is expressed as mean $+/-\mathrm{SEM} . * \mathrm{p}<0.05$ IL- $1 \beta$ Vs control, ${ }^{\wedge} \mathrm{p}<0.05$ IL- $1 \beta+\mathrm{LXA} \mathrm{V}^{\mathrm{V}}$ IL- $1 \beta$ ANOVA $\mathrm{n}=4$

\section{LXA4 increased MDA-MB231 cells expression of miRNA146}

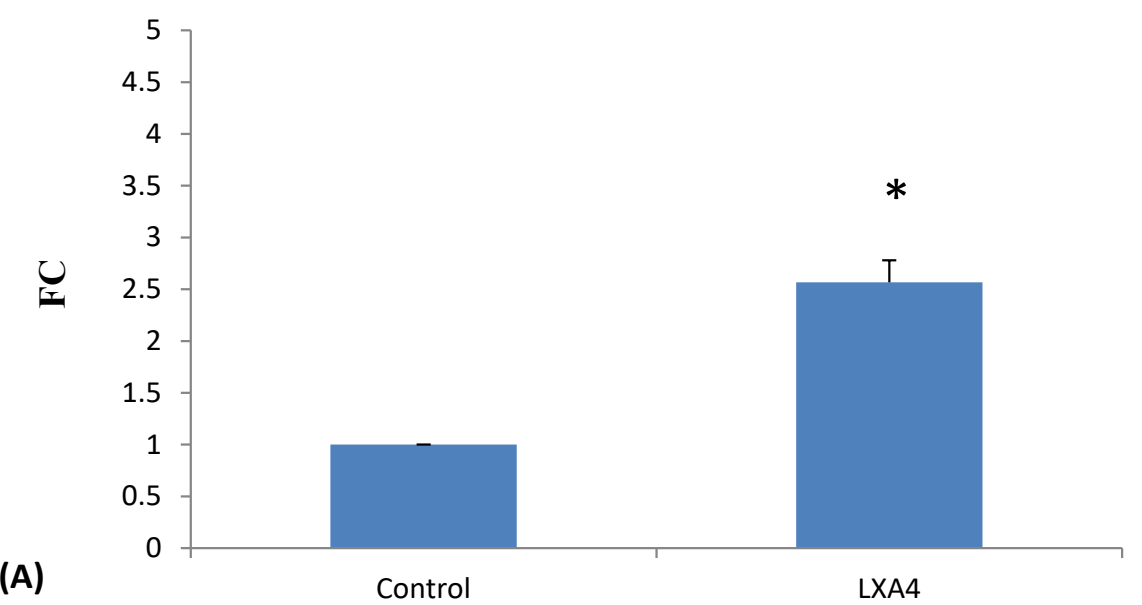

\section{LXA4 increased 4T1 cells experssion of miRNA146}

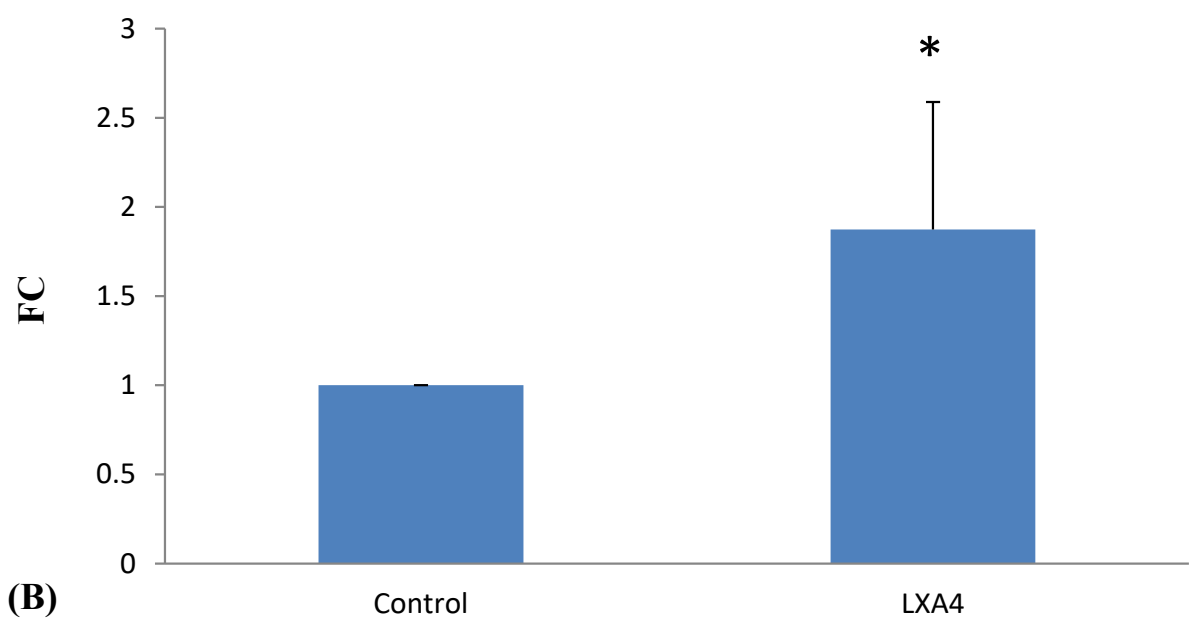

Figure 6. $\mathrm{LXA}_{4}$ treatment for $4 \mathrm{hrs}$ significantly increases MDA-MB231 and $4 \mathrm{~T} 1$ tumour cell expression of miRNA 146 as assessed PCR. Data are expressed as means and are representative of 4 separate experiments. LXA $_{4}$ Vs control ${ }^{*} p<0.05$ for MDA-MB231 (A). ${ }^{*} p<0.079$ for 4T1 (B), ANOVA. 


\section{Discussion}

Surgery augments the invasion capacity of free malignant cells by inducing the release of MMPs [31] and by enhancing adhesionmolecule expression on tumour cells [32]. Our data shows that LXA4 significantly down regulates adhesion receptor expression on tumor cells and reduces tumour cell invasion. ICAM-1 adhesion receptor is known to activate cancer cells promoting cell motility, invasion and metastasis [33]. LXA4 downregulated ICAM-1 expression on both murine and human breast cancer cells.

Circulating neutrophils have been identified in close association with metastatic tumour cells throughout the process of tumour cell arrest and extravasation in vivo and have been shown to promote the deposition of tumour cells in the microvasculature of target organs in animal models [34-36] Neutrophil extracellular traps (NET) sequester circulating tumour cells and assist metastasis [37]. This work demonstrates that LXA4 reduces the rolling receptor L-selectin and the adhesion receptor $\mathrm{CD} 11 \mathrm{~b}$ on $\mathrm{PMN}$ that have been cultured in a tumour environment.

Many silenced miRNAs appear to act as tumour suppressors by targeting oncogenes, thus re-expression of the miRNAs could be an effective approach to cancer therapy [38]. Our miRNA data demonstrated that LXA4 treatment increases miR-146b expression in human breast cancer cells. Hurst $e$ al previously linked the miR146 family to metastasis in breast cancers, showing that Breast Cancer Metastasis Suppressor 1 (BRMS1) significantly up-regulates miR-146 expression which in turn down-regulated the expression of epidermal growth factor receptor (EGFR), inhibiting invasion and migration in vitro and significantly suppressing lung metastasis in a murine model [24]. Decreased miR-146a expression also contributes to the up-regulation and overexpression of COX-2 in lung cancer cells [39]. miR-146 has also been shown to inhibit cell migration and invasion by targeting RhoA in breast cancer [40].

Down-regulation of miR-146a and miR-146b expression in breast tissues is related to the development and deterioration of breast cancer [41]. The mechanisms underlying the immune modulating effects of LXA4 are complex. It is known that LXA inhibits VEGF-stimulated proliferation of endothelial cells $[42,43]$ and LXA $_{4}$ has been shown to reduce the stabilisation of hypoxia-inducible factor 1-alpha (HIF1a) under hypoxic conditions in a murine model of hepatocarcinoma $[44,45] . \mathrm{LXA}_{4}$ is also known to inhibited the progression of murine endometriosis by attenuating prostaglandin $\mathrm{E}_{2}$ production and estrogen signaling suggesting a selective oestrogen-receptor modulator (SERM)-like inhibition of estradiol action [46].

Surgical resection remains the essential curative modality for breast cancer despite the fact that surgical procedures can cause tumor cells to disseminate into the circulatory system, and although breast cancer surgery is classified as minor surgery, the surgical procedure produces substantial immunomodulation with significant effects on disease recurrence rates and long-term patient prognosis [47]. The perioperative period offers a therapeutic window to improve patient outcomes with adjuvant treatment, and in this context, adjunct immunomodulation with pro-resolving lipids may augment the host anti-cancer defense mechanisms in the perioperative period. Our initial work is promising and needs to be more fully elucidated in a series of in vivo experiments that explore the balance between therapeutic benefit of these lipid mediators in the perioperative period and potential adverse effects on post-operative healing of reduced innate immune responses.

\section{Declarations}

\section{Ethics approval and consent to participate}

The murine tail vein injection work was carried out under licence from the Health Products Regulatory Authority (HPRA) in Ireland in compliance with EU Directive 2010/63/EU and received ethical approval from the Royal College of Surgeons in Ireland's Ethics Committee (\#REC 595). Human volunteer blood samples were collected with informed consent of the participants. This work was granted ethical approval from the Beaumont Hospital Ethics Committee (reference number 17/88).

\section{Availability of data and material}

All data generated or analysed during this study are included in this published article. Raw data is supplied within an additional available file.

\section{Competing interests.}

The authors whose names are listed declare that they have no affiliations with or involvement in any organization or entity with any financial interest in this work and have no conflict of interest.

\section{Funding}

This work was funded by a research grant from The Beaumont Hospital Cancer Research Trust.

\section{Authors' contributions}

All persons who meet authorship criteria are listed as authors, and all authors certify that they have participated sufficiently in the work to take public responsibility for the content, including participation in the concept, design, analysis, writing, or revision of the manuscript.

H.C carried out and supervised others to assist with the experimental work and analysed the results. S.F.V. advised and assisted with the miRNA work and analysed the results. E.B. did some of the cell biology and flow cytometry experiments. A. H revised the manuscript. C.C devised the concept and experiments, wrote and edited the manuscript. All authors read and approved final manuscript.

\section{Acknowledgements}

The authors would like to acknowledge the contribution of the COST Action CA14204.

\section{References}

1. https://www.wcrf.org/dietandcancer/cancer-trends/breast-cancer-statistics accessed $4 / 32020$

2. McDevitt J, Walsh P (2016) Cancer Trends - Female Breast Cancer. National Cancer Registry. Ireland: 1-6.

3. Demicheli R, Valagussa P, Bonadonna G (2001) Does surgery modify growth kinetics of breast cancer micrometastases? Br J Cancer 85: 490-492. [Crossref]

4. Demicheli R, R.M., Hrushesky WJ, Baum M, Gukas ID (2008) The effects of surgery on tumor growth: a century of investigations. Ann Oncol 19: 1821 - 1828. [Crossref]

5. Neeman E, Ben-Eliyahu S (2013) The perioperative period and promotion of cancer metastasis: New outlooks on mediating mechanisms and immune involvement. Brain, Behav Immun 30: S32 -S40. [Crossref]

6. Pascual M, Alonso S, Parés D, Courtier R, Gil MJ, et al. (2011) Randomized clinical trial comparing inflammatory and angiogenic response after open versus laparoscopic curative resection for colonic cancer. Br J Surg 98: 50 - 59. [Crossref]

7. Mehlen P, Puisieux A (2006) Metastasis: a question of life or death. Nat Re Cancer 6: 449-458. [Crossref] 
8. Chiang N, Serhan CN, Dahlén SE, Drazen JM, Hay DW, et al. (2006) The lipoxin receptor ALX: potent ligand-specific and stereoselective actions in vivo. Pharmacol Rev 58: 463-487. [Crossref]

9. Baker N, O'Meara SJ, Scannell M, Maderna P, Godson C (2009) Lipoxin A4: antiinflammatory and anti-angiogenic impact on endothelial cells. J Immunol 182: 3819 - 3826. [Crossref]

10. Marginean A, Sharma-Walia N (2015) Lipoxins exert antiangiogenic and antiinflammatory effects on Kaposi's sarcoma cells. Transl Res 166: 111 - 133. [Crossref]

11. Cezar-de-Mello PF, Vieira AM, Nascimento-Silva V, Villela CG, Barja-Fidalgo C, et al. (2008) ATL-1, an analogue of aspirin-triggered lipoxin A4, is a potent inhibitor of several steps in angiogenesis induced by vascular endothelial growth factor. $\mathrm{Br} J$ Pharmacol 153: 956 - 965. [Crossref]

12. Simões RL, De-Brito NM, Cunha-Costa H, Morandi V, Fierro IM, et al. (2017) Lipoxin A4 selectively programs the profile of M2 tumor-associated macrophages which favour control of tumor progression. Int J Cancer 140: 346 - 357. [Crossref]

13. Chen Y, Hao H, He S, Cai L, Li Y, et al. (2010) Lipoxin A4 and its analogue suppress the tumor growth of transplanted $\mathrm{H} 22$ in mice: the role of antiangiogenesis. Mol Cancer Ther 9: 2164 - 2174. [Crossref]

14. Vieira AM, Neto EH, Figueiredo CC, Barja Fidalgo C, Fierro IM, et al. (2014) ATL-1, a synthetic analog of lipoxin, modulates endothelial permeability and interaction with tumor cells through a VEGF-dependent mechanism. Biochem Pharmacol 90: 388-396. [Crossref]

15. Obeid E, Nanda R, Fu YX, Olopade OI (2013) The role of tumor-associated macrophages in breast cancer progression (review). Int J Oncol 43: 5-12. [Crossref]

16. Antonio Sica, Schioppa T, Alberto Mantovani, Paola Allavena (2006) Tumour-associated macrophages are a distinct M2 polarised population promoting tumour progression: Potential targets of anti-cancer therapy. Eur J Cancer 42: 717-727. [Crossref]

17. Petrillo M, Zannoni GF, Martinelli E, Anchora LP, Ferrandina G, et al. (2015) Polarisation of Tumor-Associated Macrophages toward M2 Phenotype Correlates with Poor Response to Chemoradiation and Reduced Survival in Patients with Locally Advanced Cervical Cancer. PLOS One 10. [Crossref]

18. Arias-Pulido H, Chaher N, Gong Y, Qualls C, Vargas J, et al. (2012) Tumor stroma vascular endothelial growth factor $\mathrm{A}$ is predictive of poor outcome in inflammatory breast cancer. BMC Cancer 12. [Crossref]

19. Bockmeyer CL,Christgen M, Muller M, Fischer S, Ahrens P, et al. (2011) MicroRNA profiles of healthy basal and luminal mammary epithelial cells are distinct and reflected in different breast cancer subtypes. Breast Cancer Res Treat 130: 735-745. [Crossref]

20. Blenkiron C, Goldstein L, Thorne N, Spiteri I, Chin S, et al. (2007) MicroRNA expression profiling of human breast cancer identifies new markers of tumour subtype. Genome Biol 8: R214. [Crossref]

21. Tavazoie SF1, Alarcón C, Oskarsson T, Padua D, Wang Q, et al. (2008) Endogenous human microRNAs that suppress breast cancer metastasis. Nature 451: 147-152. [Crossref]

22. Li Y, Xu Y, Yu C, Zuo W (2015) Associations of miR-146a and miR-146b expression and breast cancer in very young women. Cancer Biomark 15: 881. [Crossref]

23. Garcia AI, Buisson M, Bertrand P, Rimokh R, Rouleau E, et al. (2011) Down-regulation of BRCA1 expression by miR-146a and miR-146b-5p in triple negative sporadic breast cancers. EMBO Mol Med 3: 279-290. [Crossref]

24. Hurst DR, Edmonds MD, Scott GK. , Benz, C.C., Vaidya, K S., Welch,D.R. (2009) Breast Cancer Metastasis Suppressor 1 Up-regulates miR-146, Which Suppresses Breast Cancer Metastasis. Cancer Res 69: 1279-1283. [Crossref]

25. Suzuki H, Maruyama R, Yamamoto E, Kai M (2013) Epigenetic alteration and microRNA dysregulation in cancer. Frontiers in Genetics, 4, 258. [Crossref]

26. Codagnone M, Recchiuti A, Paola L, Pierdomenico A, Cianci E, et al. (2017). Lipoxin A4 stimulates endothelial miR-126-5p expression and its transfer via microvesicles. FASEB J 31: 1856-1866. [Crossref]

27. van der Bij GJ, Oosterling SJ, Beelen RH, Meijer S, Coffey JC, et al. (2009) The perioperative period is an underutilized window of therapeutic opportunity in patients with colorectal cancer. Ann Surg 249: 727-734. [Crossref]
28. Livak KJ, Schmittgen TD (2001) Analysis of relative gene expression data using realtime quantitative PCR and the 2- $\Delta \Delta \mathrm{CT}$ method. Methods 25: 402-408. [Crossref]

29. Rzeniewicz K, Newe A, Gallardo AR, Davies J, Holt MR, et al. (2015) L-selectin regulates polarity in monocytes. Proc Natl Acad Sci US A 112: E1461-E1470.

30. Schröder C, Witzel I, Müller V, Krenkel S, Wirtz RM, et al. (2011) Prognostic value of intercellular adhesion molecule (ICAM)-1 expression in breast cancer. J Cancer Res Clin Oncol 137: 1193-201. [Crossref]

31. Bu X, Zhao C, Dai X (2011) Involvement of COX-2/PGE2 Pathway in the Upregulation of MMP-9. Expression in Pancreatic Cancer. Gastroenterol Res Pract 2011: 214269. [Crossref]

32. Dowdall JF, Winter DC, Andrews E, Laug WE, Wang JH, et al. (2002) Soluble interleukin 6 receptor (sIL-6R) mediates colonic tumour cell adherence to the vascular endothelium: a mechanism for metastatic initiation? J Surg Res 107: 1-6. [Crossref]

33. Rosette C, Roth RB, Oeth P, Braun A, Kammerer S, et al. (2005) Role of ICAM1 in invasion of human breast cancer cells. Carcinogenesis 26(5):943-50. [Crossref]

34. Wu QD, Wang JH, Condron C, Bouchier-Hayes D, Redmond HP (2001) Human neutrophils facilitatate tumour cell transendothelial migration. Am J Physiol Cell Physiol 280: C814-C822. [Crossref]

35. Jadhav S, Bochner BS, Konstantopoulos K (2001) Hydrodynamic shear regulates the kinetics and receptor specificity of polymorphonuclear leukocyte-colon carcinoma cell adhesive interactions. J Immunol 167: 5986-5993. [Crossref]

36. Crissman JD, Hatfield J, Schaldenbrand M, Sloane BF, Honn KV (1985) Arrest and extravasation of B16 amelanotic melanoma in murine lungs: a light and electron microscopic study. Lab Invest 53: 470. [Crossref]

37. Cools-Lartigue J, Spicer J, McDonald B, Gowing S, Chow S, et al. (2013) Neutrophil extracellular traps sequester circulating tumor cells and promote metastasis. J Clin Invest 123: 3446-3458. [Crossref]

38. Suzuki H, Maruyama R, Yamamoto E, Kai M (2013) Epigenetic alteration and microRNA dysregulation in cancer. Front Genet 4: 258. [Crossref]

39. Cornett AL, Lutz CS (2014) Regulation of COX-2 expression by miR-146a in lung cancer cells. RNA 20: 1419-1430. [Crossref]

40. Liu Q, Wang W, Yang X, Zhao D, Li F, et al. (2016) MicroRNA-146a inhibits cell migration and invasion by targeting RhoA in breast cancer. Oncol Rep 36: 189-196. [Crossref]

41. Li Y, Xu Y, Yu C, Zuo W (2015) Associations of miR-146a and miR-146b expression and breast cancer in very young women. Cancer Biomark 15: 881-887. [Crossref]

42. Fierro IM, Kutok JL, Serhan CN (2002) Novel lipid mediator regulators of endothelial cell proliferation and migration: aspirin-triggered-15R-lipoxin A(4) and lipoxin A(4). $J$ Pharmacol Exp Ther 300: 385-392. [Crossref]

43. Cezar-de-Mello PF, Vieira AM, Nascimento-Silva V, Villela CG, Barja Fidalgo C, et al. (2008) ATL-1, an analogue of aspirin-triggered lipoxin A4, is a potent inhibitor of several steps in angiogenesis induced by vascular endothelial growth factor. $\mathrm{Br} J$ Pharmacol 153: 956-965. [Crossref]

44. Baker N, O'Meara SJ, Scannell M, Maderna P, Godson C (2009) Lipoxin A4: antiinflammatory and anti-angiogenic impact on endothelial cells. J Immunol 182: 3819 3826. [Crossref]

45. Cezar-de-Mello PF, Nascimento-Silva V, Villela CG, Fierro IM (2006) Aspirintriggered Lipoxin A4 inhibition of VEGF-induced endothelial cell migration involves actin polymerization and focal adhesion assembly. Oncogene 25: 122-129. [Crossref]

46. Kumar R, Clerc AC, Gori I, Russell R, Pellegrini C, et al. (2014) Lipoxin A Prevents the Progression of De Novo and Established Endometriosis in a Mouse Model by Attenuating Prostaglandin $\mathrm{E}_{2}$ Production and Estrogen Signaling. PLOS ONE 9: e89742. [Crossref]

47. Boomsma MF, Slot E, Berbee M, Berkhof J, Meezenbroek EJ, et al. (2010) Breast Cancer Surgery-Induced Immunomodulation. J Surg Oncol 102: 640 -648. [Crossref]

Copyright: (C2020 Browne E. This is an open-access article distributed under the terms of the Creative Commons Attribution License, which permits unrestricted use, distribution, and reproduction in any medium, provided the original author and source are credited. 